\title{
Pelaksanaan Kegiatan Ekstrakurikuler Tenis Meja di SMA Negeri 1
}

\section{Bengkulu Selatan}

\section{T. P. Wibowo ${ }^{1, a)}$; A. Juniardi ${ }^{1}$; F. E. Perdima ${ }^{1)}$}

\section{Affiliation:}

1. Program Studi Pendidikan Jasmani FKIP UNIVED

Bengkulu

Corresponding Author:

a.

titowwibowo99@yahoo.com

\section{Abstract}

The problem in this study is the lack of extracurricular implementation of table tennis because several factors affect it, including facilities and infrastructure, student motivation, and parental support. This study aims to reveal the description of the implementation of table tennis extracurricular activities in SMA Negeri 1 Bengkulu Selatan. This type of research is descriptive. The population in this study was 30 people consisting of SMA Negeri 1 Bengkulu South students who were active in participating in table tennis extracurricular consisting of 21 sons and 9 daughters. Sampling is done by the Saturated Census (Saturated Census) technique, which is by taking the whole population, so the sample is 30 people. The results obtained from the implementation of Table Tennis Extracurricular Activities in SMA Negeri 1 Bengkulu Selatan are facilities and infrastructure in the Good category, student motivation is classified Good, and parental support is in the Good classification. 


\section{Pendahuluan}

Pendidikan adalah suatu usaha atau kegiatan dijalankan dengan sengaja, teratur dan terencana dengan maksud mengubah atau mengembangkan prilaku yang diinginkan. Sekolah sebagai lembaga formal merupakan sarana dalam rangka pencapaian tujuan pendidikan tersebut. Dalam pendidikan formal belajar menunjukan adanya perubahan yang bersifat positif sehingga pada tahap akhir akan didapat keterampilan, kecakapan dan pengetahuan baru. Hasil dari proses belajar tersebut tercermin dalam pretasi belajar.

Pelaksanaan kegiatan ekstrakurikuler olahraga tenis meja bertujuan untuk meningkatkan prestasi yang diarahkan terciptanya atlet tenis meja yang berkualitas. Untuk meningkatkan kualitas atlet secara maksimal dapat dilakukan dengan suatu pembinaan dan latihan sejak usia dini, Harsono (1995 : 4) mengatakan: 1) Perlu diupayakan pembinaan atlet sejak usia dini, 2) Adanya latihan-latihan yang teratur dan latihannya bertahap dengan terprogram, 3) Sistem kompetisi yang teratur sesuai dengan tingkat dan frekeunsinya baik secara vertikal maupun horizontal, 4) Menyediakan sarana dan prasarana olahraga.

Dari kutipan di atas dapat disimpulkan, bahwa untuk mencapai mutu dan prestasi maksimal tentunya harus melalui suatu proses, mulai sejak dini. Agar prestasi yang diharapkan dapat tercapai dengan baik sehingga meningkatkan kualitas para atlet itu sendiri sebagaimana yang telah dicantumkan dalam GBHN TAP MPR bahwa: Untuk menumbuhkan budaya olahraga guna meningkatkan kualitas manusia Indonesia sehingga memiliki tingkat kesehatan dan kebugaran yang cukup, yang dimulai sejak usia dini melalui pendidikan olahraga di sekolah.

Namun dalam pelaksanaan kegiatan ekstrakurikuler cabang olahraga tenis meja ini banyak faktor penyebab yang sampai saat ini belum terpecahkan. Faktor penyebab tersebut diantaranya seperti masih belum adanya pembinaan yang semestinya, seperti kurangnya motivasi siswa, fungsi dan tugas guru, program latihan, latar belakang pendidikan guru penjas orkes dan kualifikasi guru sebagai pelatih, sumber dana yang dimiliki, perhatian pemerintah daerah, kurangnya sarana dan prasarana yang tersedia, dukungan orang tua, dukungan dari pihak sekolah dan masyarakat.

Salah satu sekolah yang menyelenggarakan kegiatan ekstrakurikuler tenis meja ini adalah
SMA Negeri 1 Bengkulu Selatan. Kegiatan ekstrakurikuler dilaksanakan di SMA Negeri 1 Bengkulu Selatan khususnya dalam pembinaan juga belum mampu menunjukan prestasi yang diharapkan, dan belum mampu menjadi penyokong prestasi para atlet dan insan olahraga. Seharusnya kegiatan ekstrakurikuler ini dilakukan di sekolah dimulai sejak masuk sekolah SMA Negeri 1 Bengkulu Selatan agar bisa memberikan kontribusi untuk menghasilkan atlet-atlet yang berprestasi.

Berdasarkan hal di atas, untuk melihat keberadaan kegiatan ekstrakurikuler tenis meja di SMA Negeri 1 Bengkulu Selatan secara utuh perlu kiranya diadakan penelitian yang mendalam untuk dapat mengungkapkan dan mencari solusi terbaik tentang sebab-sebab belum terlaksananya kegiatan ekstrakurikuler cabang olahraga tenis meja di SMA Negeri 1 Bengkulu Selatan. Untuk itulah penulis ingin melihat tentang pelaksanaan kegiatan ekstrakurikuler cabang olahraga tenis meja di SMA Negeri 1 Bengkulu Selatan.

\section{Metode Penelitian}

Jenis penelitian ini berbentuk deskriptif untuk memberikan pengertian dan menginterprestasikan data bagaimana adanya. Data yang diperoleh akan ditampilkan apa adanya dan diinterprestasikan sesuai dengan tujuan dan pertanyaan yang telah dikemukakan. Penelitian ini bertujuan untuk mengungkapkan bagaimana pelaksanaan kegiatan ekstrakurikuler tenis meja di SMA Negeri 1 Bengkulu Selatan. Penelitian ini akan dilaksanakan di SMA Negeri 1 Bengkulu Selatan, yang dilaksanakan pada bulan Agustus s/d September 2019.

Populasi dalam penelitian ini adalah siswa SMA Negeri 1 Bengkulu Selatan yang aktif mengikuti kegiatan ekstrakurikuler tenis meja yang berjumlah 30 orang, terdiri dari 21 orang putera dan 9 orang puteri. Mengingat populasi relatif sedikit maka seluruh populasi dijadikan sampel atau teknik sampling jenuh (metode sensus) yaitu sebanyak 30 orang.

Jenis data dalam penelitian ini adalah data primer yang diperoleh langsung dari responden dan data sekunder yaitu tentang informasi tentang jumlah sampel dari pelatih atau guru Penjasorkes SMA Negeri 1 Bengkulu Selatan. Sumber data dalam penelitian ini adalah dari responden siswa SMA Negeri 1 Bengkulu Selatan yang ikut dalam kegiatan ekstrakurikuler tenis meja dengan cara 
mengisi angket sesuai dengan data yang diperlukan.

Instrumen yang dipakai untuk mengumpulkan data adalah angket atau kuesioner dengan menggunakan skala guttman. Data dianalisis dengan menggunakan rumus distribusi frekuensi dalam bentuk persentase.

\section{Hasil Penelitian dan Pembahasan}

Berdasarkan hasil penelitian yang telah diuraikan di atas, variabel sarana dan prasarana, motivasi siswa, dan dukungan orang tua merupakan faktor yang mendukung pelaksanaan ekstrakurikuler tenis meja di SMA Negeri 1 Bengkulu Selatan

\section{Sarana dan Prasarana}

Secara keseluruhan tingkat capaian sarana dan prasarana yang diperoleh dari 30 orang responden untuk 10 item pertanyaan adalah sebesar $74.7 \%$, itu artinya bahwa tingkat capaian sarana dan prasarana dalam pelaksanaan kegiatan ekstrakurikuler tenis meja di SMA Negeri 1 Bengkulu Selatan berada pada klasifikasi Baik (suharsimi, 2006 : 155).

Hasil penelitian ini dimungkinkan karena sudah didukung oleh kelengkapan sarana dan prasarana untuk latihan tenis meja, hal ini terlihat dari jawaban responden yang menyatakan bahwa di SMA Negeri 1 Bengkulu Selatan telah memiliki lapangan olahraga tenis meja yang masih layak pakai, serta memiliki net yang juga masih layak pakai untuk mendukung kegiatan ekstrakutikuler tenis meja ini, sehingga jelas terlihat bahwa fasilitas yang baik akan dapat menunjang kelancaran latihan.

Di sebuah kegiatan ekstrakurikuler dalam dunia pendidikan memang sangat diperlukan kelengkapan sarana dan prasarana. Hal ini sejalan dengan yang dijelaskan M. Yanis (1989 : 22) menyatakan: Kedudukan sarana dan prasarana di dunia pendidikan pada umumnya, khususnya pendidikan olahraga sangat memegang peranan penting. Sarana dan prasarana harus disesuaikan dengan kebutuhan dilapangan karena sangat menunjang untuk kelancaran proses belajar mengajar yang efektif dan efisien. Tanpa dukungan sarana dan prasarana yang memadai pendidikan jasmani maka akan sukarlah tujuan yang diharapkan. Kesimpulannya adalah sarana dan prasarana merupakan salah satu aspek penunjang yang sangat penting di dalam pembinaan olahraga, baik olahraga pendidikan maupun olahraga prestasi.
Berdasarkan hasil tersebut, jelas bahwa tanpa ada dukungan dari sarana dan prasarana yang memadai baik dari segi kuantitas maupun segi kualitas, hal ini berpengaruh terhadap kelancaran dalam proses latihan, sehingga dengan perlengkapan yang tidak mencukupi, maka prestasi yang diraih tidak akan memuaskan. Jadi salah satu usaha untuk meraih hasil yang baik dalam olahraga saat ini akan ditentukan oleh sarana dan prasarana, baik dari segi jumlahnya maupun mutunya. Di SMA Negeri 1 Bengkulu Selatan keadaan sarana dan prasarana sudah dapat mendukung kegiatan ekstrakurikuler tenis meja di tempat tersebut, hanya saja perlu ditambah dari segi kualitas dan kuantitasnya.

2. Motivasi

Secara keseluruhan tingkat capaian Motivasi siswa yang diperoleh dari 30 orang responden untuk 10 item pernyataan adalah sebesar $74.3 \%$, itu artinya bahwa tingkat capaian Motivasi siswa dalam pelaksanaan kegiatan ekstrakurikuler tenis meja di SMA Negeri 1 Bengkulu Selatan berada pada klasifikasi Baik.

Hasil penelitian tersebut tergambar dari indikator antusias, disiplin, dan minat siswa dalam kegiatan ekstrakurikuler di SMA Negeri 1 Bengkulu Selatan. Dari data dapat dimaknai bahwa klasifikasi baik pada motivasi disebabkan oleh minat siswa yang tinggi untuk mengikuti latihan tenis meja, yang didukung oleh variasi metode latihan guru dalam memberikan latihan. Hal ini juga didukung oleh antusianisme dan rasa senang siswa serta kegiatan ekstrakurikuler ini melatih siswa agar bersikap sportivitas dan lebih disiplin. Motivasi adalah hal yang sangat penting dalam sebuah kegiatan, karena itu merupakan sebuah pendorong unuk melakuan suatu. Hal ini sejalan dengan pendapat Pendapat ini diperkuat oleh Barelson dan Steiner dalam Gunarsa ( 1989 : 92), bahwa: Motivasi adalah kekuatan dari dalam diri untuk menggerakkan dan mengarahkan atau membawa tingkahlaku ke tujuan. Sesuai dengan pendapat tersebut jelas terlihat bahwa motivasi merupakan kumpulankumpulan perasaan, kesenangan-kesenangan, kecenderungan, dan dorongan insting, yang menampak sebagai minat yang tercipta sebagai tindakan atau perlakuan untuk mencapai tujuan tertentu.

Berdasarkan kutipan di atas fungsi motivasi adalah mendorong manusia untuk berbuat, menentukan arah perbuatan, untuk mencapai 
tujuan dan menyeleksi perbuatan yakni perbuatan mana yang akan dikerjakan.

Berdasarkan hasil tersebut di atas, jelas bahwa tanpa adanya motivasi yang baik dari siswa, maka kemauan dan keseriusan siswa dalam berlatih ataupun bertanding akan berkurang. Motivasi adalah pendorong yang menjadikan terealisasinya aktivitas. Munculnya keinginan untuk beraktivitas menunjukkan adanya motif pendorong pelaku aktifitas tersebut. Sejak lahir manusia telah membawa motif-motif tertentu. Dengan motif itu individu berusaha memenuhi kebutuhankebutuhannya, terutama untuk kelangsungan hidupnya. sehingga dengan motivasi baik, pencapaian prestasi akan dilakukan secara optimal.

Jadi salah satu usaha untuk meraih hasil yang baik dalam olahraga saat ini akan ditentukan oleh keadaan motivasi siswa, baik motivasi instrinsik maupun ekstrinsik. Di SMA Negeri 1 Bengkulu Selatan keadaan motivasi siswa sudah dapat diklasifikasikan Baik jadi diharapakan dengan keadaan motivasi yang seperti itu diharapkan dapat membantu dalam pencapaian prestasi yang lebih tinggi.

\section{Dukungan Orang Tua}

Secara keseluruhan tingkat capaian dukungan orang tua yang diperoleh dari 30 orang responden untuk 10 item pertanyaan adalah sebesar $64.3 \%$, itu artinya bahwa tingkat capaian dukungan orang tua terhadap kegiatan pemibaan ekstrakurikuler olahraga bolavoli yang ada di SMA Negeri 1 Bengkulu Selatan berada pada klasifikasi Baik.

Hasil penelitian ini dipengaruhi oleh indikator perhatian dan peranan orang tua terhadap keberhasilan anaknya, dan juga faktor tugas dan kewajiban orang tua serta hubungan antara orang tua dengan anak dan guru yang memotivasi latihan anak. Untuk indikator perhatian dan peranan orang tua tergambar dengan memberikan perlengkapan yang dibutuhkan anak, serta mengantar dan menjemput siswa saat melakukan latihan, hal lain juga tergambar dengan orang tua yang memberikan makanan dan minuman yang bergizi agar anak tetap sehat dalam melakuan latihan.

Dukungan orang tua merupakan faktor yang sangat penting dalam memotivasi anak dalam pencapaian prestasi yang optimal. Hal ini dikarenakan bahwa orang tua lebih banyak mengetahui tentang perkembangan anaknya, apakah anak tersebut mempunyai minat, bakat dalam kegiatan ekstrakurikuler, dan apabila diketahui tentang minat tersebut, maka seharusnya orang tua memberikan dukungan moral atau materi untuk memacu terlaksananya kegiatan ekstrakurikuler di sekolah. Kegiatan ini diharapkan agar nantinya dapat menguasai keterampilan serta berprestasi, karena salah satu wadah untuk menyalurkan minat dan bakat siswa dalam cabang olahraga tersebut.

\section{Kesimpulan}

Berdasarkan hasil penelitian tentang pelaksanaan kegiatan ekstrakurikuler tenis meja di SMA Negeri 1 Bengkulu Selatan maka dapat ditarik kesimpulan: (1) Tingkat capaian sarana dan prasarana dalam pelaksanaan kegiatan ekstrakurikuer tenis meja di SMA Negeri 1 Bengkulu Selatan berada pada klasifikasi Baik. (2) Tingkat capaian Motivasi siswa dalam pelaksanaan kegiatan ekstrakurikuler olahraga bolavoli yang ada di SMA Negeri 1 Bengkulu Selatan berada pada klasifikasi Baik. (3) Tingkat capaian dukungan orang tua dalam peaksanaan kegiatan ekstrakurikuler tenis meja di SMA Negeri 1 Bengkulu Selatan berada pada klasifikasi Baik.

\section{Daftar Pustaka}

Harsono. 1995. Coaching dan Aspek-Aspek Psikologi Dalam Coaching. Jakarta: Akademi Presindo.

Sardiman. S. Arief dkk. 2003. Media Pendidikan Pustelkom departemen Pendidikan dan Kebudayaan.

Santoso, 1984, Supervisi Pendidikan Olahraga VI : Jakarta.

Setyobroto. 2002. Psikologi Olahrga. Jakarta : UNJ

Suharsimi, Arikunto. 2006. Prosedur Penelitian Suatu Pendekatan Praktek, Edisi Revisi VI. Jakarta : PT. Rineka Cipta.

Syafruddin 2012. ILMU KEPELATIHAN OLAHRAGA (Teori Dan Aplikasinya Dalam Pembinaan Olahraga). Padang. UNP Perss

Undang-Undang Republik Indonesia Nomor 3 Tahun 2005. Tentang Sistem Keolahragaan Nasional. Jakarta Kementrian Negara Pemuda dan Olahraga Republik Indonesia

Yanis, M. 1989. Pelaksanaan Kurikulum di SMA Kodya Padang. Padang: Perpustakaan UNP. 